$\begin{array}{ll}\text { Nama } & : \text { Nur Hikmah } \\ \text { NIM } & : 90100118014 \\ \text { Kelas } & : \text { Ekonomi Islam A }\end{array}$

\title{
SISTEM EKONOMI KAPITALIS
}

Dalam ekonomi kapitalis, dua pasar memainkan peran yang sangat penting dalam sistem ekonomi. Ekonomi kapitalis membutuhkan pasar bebas untuk menyelesaikan masalah ekonomi, mulai dari produksi, konsumsi, dan distribusi. Perilaku kapitalis adalah lassez faire et laissez le monde va de lui meme (Biarkan bekerja dan dunia akan mengurus dirinya sendiri). Artinya dengan membiarkan perekonomian berfungsi dengan baik tanpa campur tangan pemerintah, maka akan ada tangan-tangan tak kasat mata yang akan menstabilkan perekonomian. Jika pemerintah turun tangan, pasar akan mengalami distorsi yang berujung pada ketidakefisienan dan ketimpangan ekonomi. ( Idris Parakasih, 2018)

Kapitalisme didorong oleh motif keuntungan yang kuat yang mengatur penawaran dan permintaan. Dalam kapitalisme, banyak kekuatan bersama-sama yang menghasilkan pola berulang mengutamakan kekhasan sejarah dan regional: motif keuntungan menjadi yang paling kuat di kekuatan ini. Intensitas persaingan dalam kapitalisme tidak tergantung pada jumlah perusahaan di pasar tertentu. Persaingan nyata bergolak dan antagonis, karena keuntungan mencari adalah ekspansif dan membuat perusahaan melawan satu sama lain. (Patomäki, 2017)

Konsep pasar Smith menarik perhatian pada masalah yang penting bagi kekayaan sosial. Ini menggabungkan beberapa faktor yang sebelumnya yang tidak dianggap penting bagi kekayaan negara. Smith mencoba untuk fokus pada apa. Penting bagi pendiriannya dari masyarakat pasar yang sesungguhnya. Jadi, tidak seperti gravitasi yang merupakan hal yang wajar hukum dan pasar adalah sebuah institusi . Disadari atau tidak, file pasar adalah hasil dari aktivitas manusia, hubungan dan pilihan. Bisa jadi subjek dan objek wacana dan pilihan politik. Namun, Sebagaimana manusia tidak sepenuhnya menguasai sentimen moral mereka, mereka melakukannya belum tentu menyadari apa yang sebenarnya sedang terjadi dan apa yang pentingaktivitas pasar. (Bouchet, 2017) 
Bagi Marx, ciri utama kapitalisme adalah pemisahan antara pemilik sarana produksi (kapitalis atau borjuasi) dan bukan pemilik alat produksi (pekerja, buruh atau proletariat). Karl Marx menganggap kapitalisme sebagai mode yang spesifik secara historis produksi dan kapitalisme dianggap sebagai fase perkembangan ekonomi yang akan berlalu dan digantioleh komunisme murni. (Anthony, 2012)

Dalam system ekonomi kapitalis, harga mempunyai peranan dalam kegiatan produksi, konsumsi, dan distribusi melalui struktur harga. (1) Dalam bidang produksi, harga menentukan siapa saja produsen yang boleh masuk dalam area produksi dan siapa saja yang tidak boleh masuk atau keluar dari area produksi (2) Pada bidang konsumen, harga merupakan alat pengendali yang menentukan kemampuan konsumen dalam memenuhi berbagai kebutuhan dan keinginannya. (3) Stuktur harga sebagai titik pertemuan antara penawaran produsen dan permintaan konsumen merupakan metode distribusi dalam sistem ekonomi kapitalis 


\section{DAFTAR PUSTAKA}

Bouchet, D. (2017). Adam Smith , Market and Social Change: Then and Now. Markets, Globalization \& Development Review, 2(1).

Parakkasi, I., \& Kamiruddin, K. (2018). Analisis Harga Dan Mekanisme Pasar Dalam Perspektif Islam. LAA MAISYIR : Jurnal Ekonomi Islam, 5(1), 107-120.

Patomäki, H. (2017). Capitalism: Competition, Conflict, Crisis. Journal of Critical Realism, 16(5), 537-543.

Sterritt, D. (2017). Race Movies: Pioneers of African-American Cinema (Kino Lorber). Quarterly Review of Film and Video, 34(2), 198-200. 